\title{
Quality characteristics of fermented soybean products produced by lactic acid bacteria isolated from traditional soybean paste
}

\author{
Sun Young Lee ${ }^{1}$, Bo Young Seo ${ }^{1}$, Jeong Seon Eom ${ }^{1}$, Hye Sun Choi ${ }^{2 *}$ \\ ${ }^{1}$ National Institute of Agricultural Science, Rural Development Administration, Wanju 55365, Korea \\ ${ }^{2}$ National Institute of Crop Science, Rural Development Administration, Suwon 16616, Korea
}

\section{전통 장류 유래 유산균을 이용한 콩 발효물의 품질특성}

\author{
이선영 ${ }^{1} \cdot$ 서보영 $^{1} \cdot$ 엄정선 $^{1} \cdot$ 최혜선 ${ }^{2 *}$ \\ ${ }^{1}$ 농촌진흥청 국립농업과학원, ${ }^{2}$ 농촌진흥청 국립식량과학원
}

\begin{abstract}
This study evaluated quality characteristics of soybean fermented by selected lactic acid bacteria, which were the enzyme strains with high antimicrobial activities isolated from traditionally prepared soybean paste. We determined total aerobic and lactic acid bacteria counts, protease and amylase activities, reducing sugar and amino-type nitrogen contents, and the amounts of amino acids, organic acids, and aroma-compounds. The total aerobic bacteria counts in soybean fermented with strain $\mathrm{I13}\left(7.75 \times 10^{9} \mathrm{CFU} / \mathrm{mL}\right)$ were the highest among all the strains analyzed. Lactic acid bacteria numbers were $2.85 \times 10^{9}$ to $4.35 \times 10^{9} \mathrm{CFU} / \mathrm{mL}$ in soybean fermented with isolates. Amylase and protease activities of the JSB22 sample were the highest among all sample. Reducing sugar and amino-type nitrogen contents of soybean fermented with JSB22 $(1.23 \%, 94.52 \mathrm{mg} \%)$ were highest. Total amino acid content of the samples was 15.88-17.62\%, and glutamic acid, aspartic acid, leucine, lysine, and arginine were the major amino acids. Lactic acid (0.82-3.65 g/100 g), oxalic acid (22.74-63.57 mg/100 g), and fumaric acid (2.88-6.33 mg/100 g) were predominant organic acids. A total of 39 volatile aroma-compounds were identified, including 2 esters, 5 ketones, 7 alcohols, 14 hydrocarbons, 2 heterocyclic compounds, 4 acids, and 5 miscellaneous compounds. These results represent useful information for the development of a starter (single or complex) and will be used for production of functional fermented soybean foods.
\end{abstract}

Key words : fermented soybean products, lactic acid bacteria, quality characteristics, flavor compounds

\section{서 론}

콩은 단백질 뿐 만 아니라 식이섬유, 인지질, isoflavonoids, phenolic acids, saponins, trypsin inhibitor, phytic acid 등의 유용성분이 함유되어 있는 것으로 알려져 있다. 콩을 원료 로 하는 발효식품인 된장, miso, tempeh는 발효미생물 유래 효소에 의해 분해 작용 및 생물전환에 의해 생리활성물질을

*Corresponding author. E-mail : choihs9587@korea.kr Phone : 82-63-238-3624, Fax : 82-63-238-3843

Received 21 September 2016; Revised 18 November 2016; Accepted 14 April 2017.

Copyright (c) The Korean Society of Food Preservation. All rights reserved.
생산하게 되는데, 대표적인 유용물질인 isoflavone은 발효 과정 중 비배당체로 되어 체내 흡수되기 좋은 상태로 변형 된다 $(1,2)$. 청국장은 콩 발효식품 중 발효기간이 가장 짧으 며, 그 풍미가 독특하고 여러 가지 필수아미노산과 식물성 지방 및 유기산 들을 많이 함유하여 영양적으로도 우수한 식품으로 알려져 있다. 특히 청국장의 품질을 나타내는 지 표로는 맛, 향, texture, 색, 기능성 등이 있고, 이러한 특징은 발효미생물에 의해 많은 영향을 받는다(3). 전통 청국장의 특유한 냄새를 완화시키기 위해 생리활성물질이 우수한 균주(4), 효소활성과 항균활성이 뛰어난 Bacillus sp. 균주(5) 를 이용한 연구가 있다. Yang 등(6)은 고초균과 유산균을 이용하여 두유 요구르트를 제조하여 콩 비린내를 저감화 하였으며, Jang 등(7)은 Lactobacillus와 Bifidobacterium과 
같은 유산균을 발효두유에 접목하였다. Lee 등(8)은 soybean yogurt 제조 시 두유나 대두단백을 효소 처리하여 콩 비린내를 감소시키고 유산균의 생육이 촉진 된다는 것을 확인하였다.

유산균은 다양한 발효식품 제조에 사용되어 온 GRAS (Generally recognized as safe) 미생물로 알려져 있으며, 프 로바이오틱스(probiotics) 균주가 많이 포함되어져 있다. 유 산발효식품의 경우, 특유의 풍미 및 보존성을 부여할 뿐만 아니라 유당 불내증 완화작용, 정장작용, 병원성 균에 대한 항균작용, 콜레스테롤 저하작용, 항암작용, 면역 조절작용 의 효과가 알려져 있다(9-11).

발효소재 다양성을 위한 국내 토종 유산균을 이용한 콩 발효 기반연구는 아직 부족한 실정이다. 유산균 콩 발효물 은 식품학적 기능뿐만 아니라 맛, 향 및 보존성 유지에 관여 하는 물질을 생성할 뿐만 아니라 probiotic 효과도 기대 할 수 있을 것으로 사료된다. 따라서 본 연구에서는 probiotic 효과가 우수한 유산균을 이용하여 콩 발효물을 제조한 후 미생물학적 특성, 유리아미노산, 유기산 함량, 휘발성 향기 성분 등을 분석하여 기초자료로 사용하고자 하였다.

\section{재료 및 방법}

\section{유산균 이용 콩발효물 제조}

대두를 침지 $\left(20^{\circ} \mathrm{C}, 18 \mathrm{~h}\right)$ 한 후, autoclave를 이용하여 증자 $\left(100^{\circ} \mathrm{C}, 2 \mathrm{~h}\right)$ 하였으며, 증자된 콩을 방냉 $\left(40^{\circ} \mathrm{C}\right.$ 이하) 하였다. MRS broth(Difco, Sparks, MD, USA)로 전 배양된 유산균 $\left(\mathrm{OD}(600 \mathrm{~nm}): 0.5,10^{8} \mathrm{CFU} / \mathrm{mL}\right)$ 을 증자콩에 $1 \%$ 접종 $(\mathrm{v} / \mathrm{w})$ 하여 발효 $\left(\mathrm{RH} 70 \%, 37^{\circ} \mathrm{C}, 36 \mathrm{~h}\right)$ 시료를 제조하였다. Control 의 경우, 균을 접종하지 않고 동일한 조건에서 발효 $\left(\mathrm{RH} 70 \%, 37^{\circ} \mathrm{C}, 36 \mathrm{~h}\right)$ 하여 시료로 사용하였다. 본 실험에 사용 된 균주는 전통 장류 유래 유산균주로 통성혐기성의 특성을 가지며 exopolysaccharide 생성, 항균활성, 내산성, 내담즙성 활성을 나타내는 프로바이오틱 효과 우수 균주인 Lactococcus lactis I13, Lactobacillus plantarum JSA22, $L$. brevis JSB22를 이용하였다(12).

\section{추출물 제조}

콩 발효물 $20 \mathrm{~g}$ 에 증류수를 가하여 $100 \mathrm{~mL}$ 이 되도록 정용하고 균질화한 후, 이를 원심분리 $(8,000 \times \mathrm{g}, 10 \mathrm{~min})$ 하 여 상등액을 시료 추출액으로 사용하였다.

\section{미생물수 측정}

총 균수와 유산균수 측정은 각 시료 $1 \mathrm{~g}$ 을 멸균 생리식염 수를 이용하여 10 진 희석법에 의해 10 단계로 희석한 후, 희석액을 총 균수는 plate count agar(Difco, Sparks, MD, $\mathrm{USA})$ 에 도말하여 배양 $\left(37^{\circ} \mathrm{C}, 24 \mathrm{~h}\right)$ 한 후, 결과를 계수 하여
측정하였고, 유산균수는 MRS agar(Difco, Sparks, MD, USA)에 도말하여 gas pack(Oxoid, Hampshire, England)을 이용하여 혐기조건으로 배양 $\left(37^{\circ} \mathrm{C}, 48 \mathrm{~h}\right)$ 한 후, 결과를 계수 하여 colony forming unit $(\log \mathrm{CFU} / \mathrm{mL})$ 로 나타내었다.

\section{Protease 활성측정}

Protease의 활성은 Kim 등(13)의 방법을 변형하여 측정하 였다. 시료 추출액 $1 \mathrm{~mL}$ 에 $0.6 \%$ casein기질용액 $(0.2 \mathrm{M}$ phosphate buffer, $\mathrm{pH}$ 7.0)를 넣고 $37^{\circ} \mathrm{C}$ 에서 10 분간 반응시켰 다. 반응 후 $0.44 \mathrm{M}$ trichloroacetic acid(TCA) $5 \mathrm{~mL}$ 를 넣어 반응을 중지시켰다. 실온에서 30 분간 방치한 다음 여과지 (No.2, Whatman, Buckinghamshire, UK)에 여과한 여액 2 $\mathrm{mL}$ 에 $0.55 \mathrm{M} \mathrm{Na}_{2} \mathrm{CO}_{3}$ 용액 $5 \mathrm{~mL}$ 와 4 배 희석된 Folin reagent 용액 $1 \mathrm{~mL}$ 를 넣어 실온에서 30 분간 반응시킨 후, $660 \mathrm{~nm}$ 에 서 흡광도를 측정하였다. 표준물질 tyrosine(Sigma Co., St. Louis, MO, USA)을 단계적으로 희석하여 동일한 방법으로 분석된 standard curve를 이용하여, 1 unit은 1 분 동안 tyrosine $1 \mu \mathrm{g}$ 을 유리시키는 양을 환산하여 나타내었다.

\section{$a-A m y l a s e$ 활성측정}

a-Amylase활성 측정은 DUN(Dextrinogenic unit of nagase) 법에 의하여 측정하였다(5). $1 \%$ 가용성전분(in $0.02 \mathrm{M}$ phosphate buffer, $\mathrm{pH}$ 7.0) $3 \mathrm{~mL}$ 에 시료 추출액 $1 \mathrm{~mL}$ 첨가하 여 $40^{\circ} \mathrm{C}$ 에서 10 분간 반응시킨 후, $1 \mathrm{M} \mathrm{HCl} 10 \mathrm{~mL}$ 를 가하여 반응을 중지시켰다. 요오드 용액 $\left(0.005 \% \mathrm{I}_{2}+0.05 \% \mathrm{KI}\right) 10$ $\mathrm{mL}$ 을 넣고 발색시킨 후, $660 \mathrm{~nm}$ 에서 흡광도를 측정하였다. 공시험을 $1 \mathrm{M} \mathrm{HCl} 10 \mathrm{~mL}$ 를 넣어 반응을 중지후 시료추출액 을 넣어 반응 시킨 후, 발색시켜 측정하였다. 조효소액 1 $\mathrm{mL}$ 이 1 분 동안 전분 $0.1 \mathrm{mg}$ 을 분해한 양을 1 unit으로 계산 하였다.

\section{아미노태 질소 함량측정}

아미노태 질소 함량은 Formol 적정법(14)으로 측정하였 다. 시료 추출용액 $5 \mathrm{~mL}$, 중성 formalin용액 $10 \mathrm{~mL}$ 및 증류 수 $10 \mathrm{~mL}$ 을 혼합한 용액에 $0.5 \%$ phenolphthalein용액 2-3방 울 가한 후, 이에 $0.1 \mathrm{~N} \mathrm{NaOH}$ 를 가하여 미홍색이 될 때까지 의 적정량과 blank test의 적정량을 이용하여 산출하였다.

\section{환원당 함량측정}

환원당 함량은 dinitrosalicylic acid(DNS)법(15)으로 측정 하였다. DNS 시약 $3 \mathrm{~mL}$ 과 희석한 시료 추출용액 $1 \mathrm{~mL}$ 를 가하고 $37^{\circ} \mathrm{C}, 5$ 분간 반응 후, 냉각시킨 다음 $550 \mathrm{~nm}$ 에서 흡광도를 측정하였으며, glucose를 이용한 표준곡선으로부 터 환원당 함량을 산출하였다.

유리 아미노산 및 유기산 함량분석

유리 아미노산함량은 Lee 등(16)의 방법을 이용하여 측 
정하였다. 시료 3에 $70 \%$ ethanol $30 \mathrm{~mL}$ 를 가하여 균질화(1 h)한 후, 원심분리 $(21,000 \times \mathrm{g}, 15 \mathrm{~min})$ 하였다. 상등액을 $70 \%$ ethanol $25 \mathrm{~mL}$ 로 2회 반복 추출하고 추출액을 합하여 감압 농축하였으며, 이를 $0.02 \mathrm{~N} \mathrm{HCl} 20 \mathrm{~mL}$ 에 녹이고 10 배 희석하여 $0.45 \mu \mathrm{m}$ membrane filter로 여과한 후 아미노산 자동분석기(Blochrom 30, Biochrom Ltd., Cambrdge, UK)를 이용하여 분석하였다.

유기산 함량 분석을 위한 시료 $3 \mathrm{~g}$ 을 $50 \mathrm{~mL}$ volumetric flask에 넣고 증류수 $30 \mathrm{~mL}$ 을 첨가한 후 한 시간 동안 균질 화 하였다. 실온으로 식힌 후 증류수 가하며, $50 \mathrm{~mL}$ 로 정용 하고 filter paper로 여과한 후 $0.45 \mu \mathrm{m}$ filter로 여과하여 시험용액으로 사용하였다. 유기산 표준물질은 시료와 동일 하게 처리한 후 검량선 작성의 시료로 사용하였다. 유기산 분석을 위한 기기는 HPLC(Agilent technologies, Palo alto, CA, USA), column은 cap cell pak C18-AQ(Phenomenex, Torrance, CA, USA), detector는 UV $210 \mathrm{~nm}$, mobile phase는 $0.1 \mathrm{M}$ $\mathrm{NH}_{4} \mathrm{H}_{2} \mathrm{PO}_{4}(\mathrm{pH} 2.5)$ 를 isocratic 조건으로 사용하였으며, flow rate 는 $1.0 \mathrm{~mL} / \mathrm{min}$ 의 조건으로 분석하였다.

\section{향기 분석}

시료 $2 \mathrm{~g}$ 에 추출용매(diethyl ether: pentane=1:1) $10 \mathrm{~mL}$ 을 가하여 진탕추출 $\left(20^{\circ} \mathrm{C}, 15 \mathrm{~h}\right)$ 한 후, 원심분리 $(10,017 \times g 10$ $\min$ )하였고 상등액에 sodium sulfate $1 \mathrm{~g}$ 을 첨가하여 수분을 흡착시켰다. 상등액을 여과(No. 2, Whatman, Buckinghamshire, $\mathrm{UK}$ )한 후, 여액을 $0.2 \mu \mathrm{m}$ syringe filter(Merck Millipore, Darmstadt, Germany)로 반복 여과하여 분석 시료로 사용하 였다. 향기 성분 분석은 GC/MS(QP2010, Shimadzu, Kyoto, Japan)를 이용하였고, 컬럼은 HP-innowax(60 m/ID $0.25 \mu \mathrm{m}$, Agilent, Santa Clara, CA, USA)를 사용하였다. 오븐온도는 $40^{\circ} \mathrm{C}$ 에서 5 분 동안 유지한 후 1 분당 $2^{\circ} \mathrm{C}$ 씩 $230^{\circ} \mathrm{C}$ 까지 상승 시켰고, 30 분 동안 유지하였다. Injection온도는 $250^{\circ} \mathrm{C}$, carrier gas는 헬륨 $(\mathrm{He})$ 을 이용하였고, 이동상 유속은 0.74 $\mathrm{mL} / \mathrm{min}$ 로 하였다. 화합물 동정은 $\mathrm{GC}-\mathrm{MS}$ 로 얻은 mass spectrum을 Wiley275 data base로 검색하여 동정하였다. 정 량분석을 위하여 각 화합물의 함량은 $50 \mathrm{ppm}$ 농도의 내부 표준물질 4-methyl-2-pentanol(Sigma Co.)을 이용하여 정량 하였다.

\section{통계 분석}

실험결과는 3회 반복으로 측정하였으며, 평균치간의 유 의성 검증은 SPSS system(Statistical Pack-age for Social Sciences, SPSS Inc, Chicago, IL, USA) soft-ware package (version 12)를 이용, $\mathrm{p}<0.05$ 수준으로 Duncan's multiple range test에 의하여 검정하였다.
A

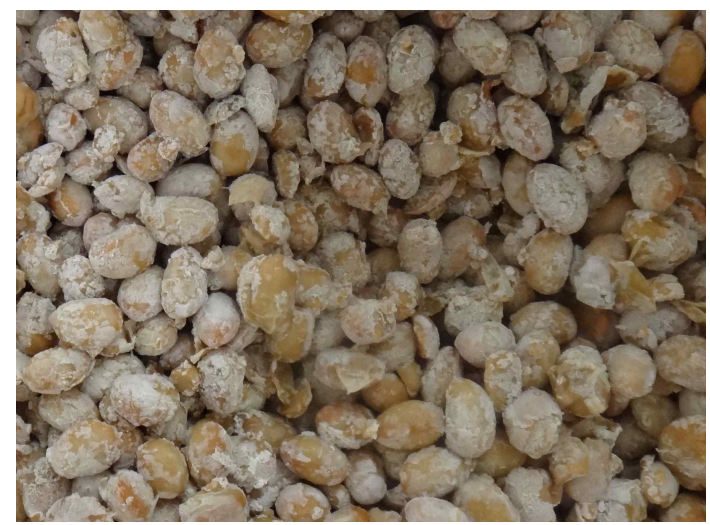

C

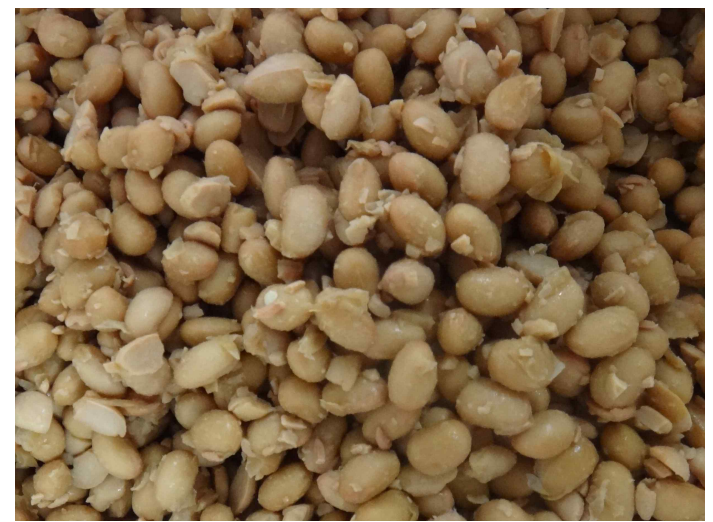

B

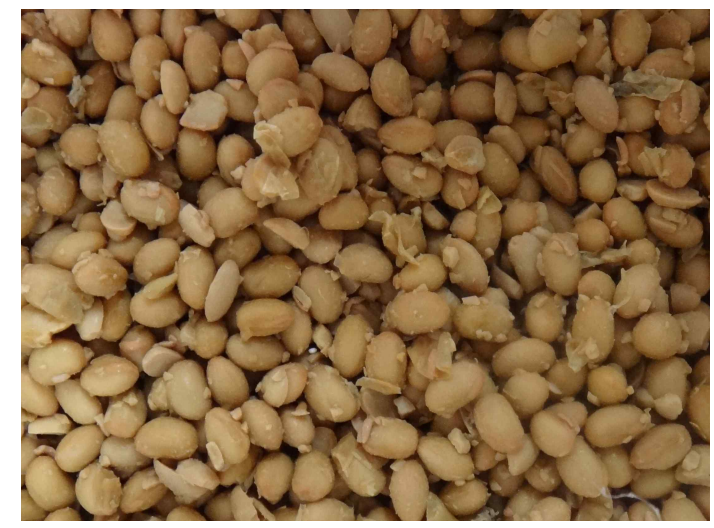

D

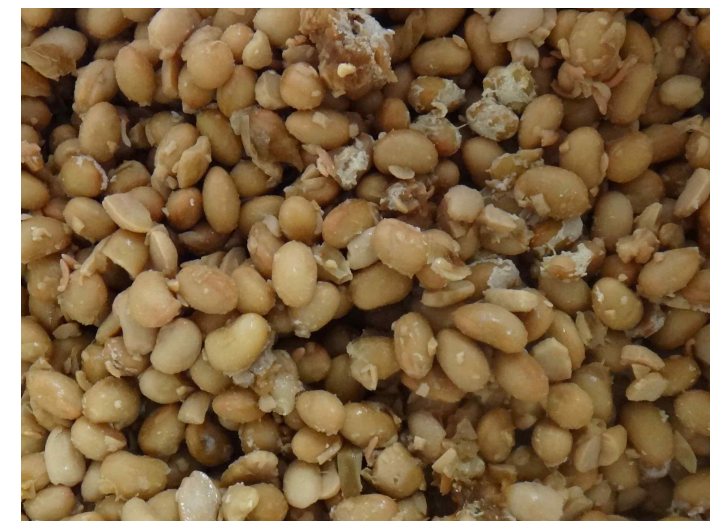

Fig. 1. Pictures of soybean fermented by lactic acid bacteria isolated from fermented soybean paste.

(A), Control; (B), Lactococcus lactis I13; (C), Lactobacillus plantarum JSA22; (D), L brevis JSB22. 

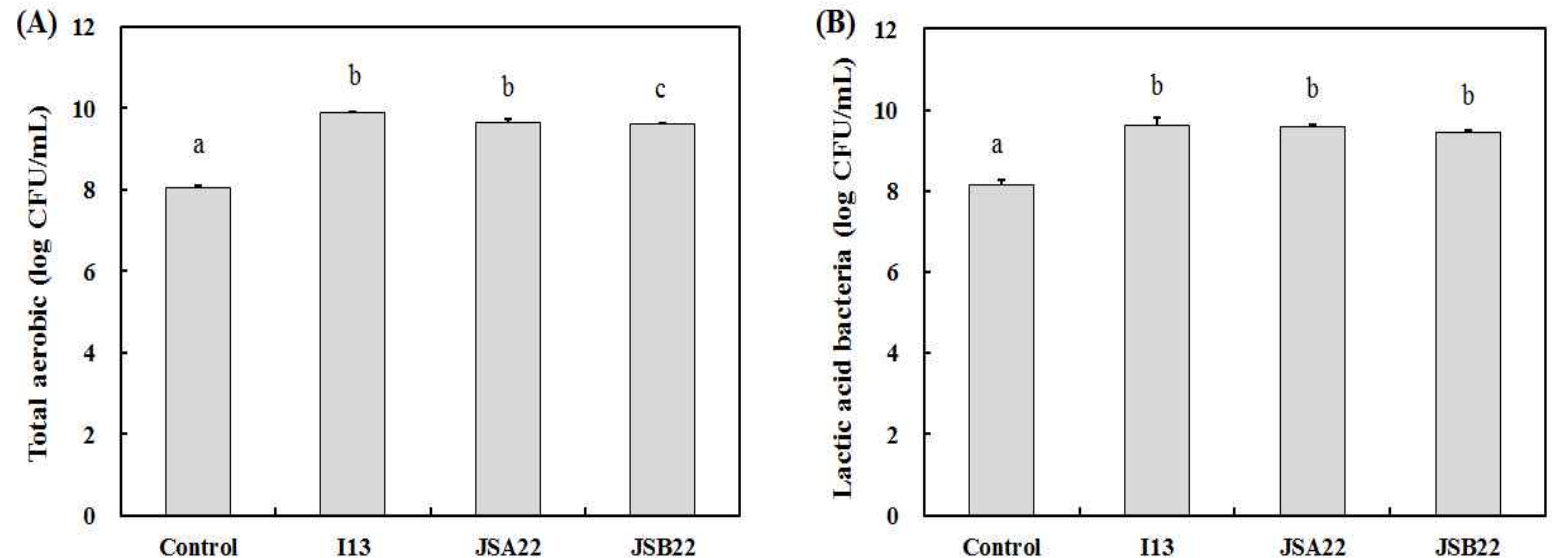

Fig. 2. Total aerobic and lactic acid bacteria count of fermented soybean products by lactic acid bacteria isolated from fermented soybean paste.

(A), total aerobic; (B), lactic acid bacteria.

Control, no inoculation; I13, Lactococcus lactis I13; JSA22, Lactobacillus plantarum JSA22; JSB22, L brevis JSB22

Error bars represent standard deviations $(\mathrm{n}=3)$. Means with different letters $(\mathrm{a}-\mathrm{c})$ above the bars are significantly different $(\mathrm{p}<0.05)$.
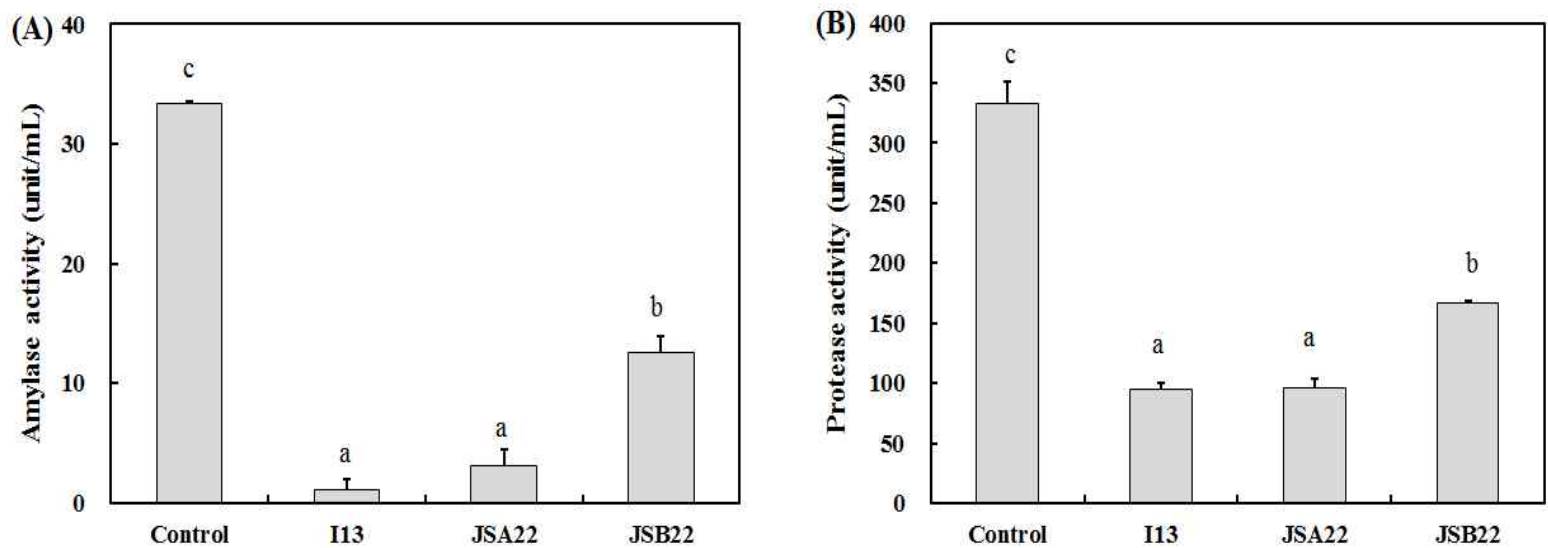

Fig. 3. Enzyme activity of fermented soybean products by lactic acid bacteria isolated from fermented soybean paste.

(A), amylase activity; (B), protease activity.

Control, no inoculation; I13, Lactococcus lactis I13; JSA22, Lactobacillus plantarum ISA22; JSB22, L brevis JSB22.

Error bars represent standard deviations $(\mathrm{n}=3)$. Means with different letters $(\mathrm{a}-\mathrm{c})$ above the bars are significantly different $(\mathrm{p}<0.05)$.

\section{결과 및 고찰}

\section{미생물 측정}

콩 발효물의 일반세균수와 유산균수를 측정한 결과는 Fig. 2 와 같다. 일반세균수는 control이 $1.12 \times 10^{8} \mathrm{CFU} / \mathrm{mL}$ 으 로 가장 낮았으며, 유산균을 접종한 콩 발효물은 $4.10 \times 10^{9}$ $-7.75 \times 10^{9} \mathrm{CFU} / \mathrm{mL}$ 으로 높게 나타났다. 또한 유산균수를 측정한 결과, 균을 접종하지 않은 control이 $1.40 \times 10^{8}$ $\mathrm{CFU} / \mathrm{mL}$ 로 측정되었으며, 유산균을 접종한 콩 발효물은 $2.85 \times 10^{9}-4.35 \times 10^{9} \mathrm{CFU} / \mathrm{mL}$ 로 높게 나타났다. 유산균 종류 에 따른 균수 차이는 나타나지 않았으며, 콩에 유산균이 우점 하여 발효가 잘 되었음을 확인할 수 있었다. Yang
등(6)은 두유에 유산균과 고초균을 혼합 접종하였을 때, 총균수의 변화는 유산균만 접종한 군은 $1.02 \times 10^{8} \mathrm{CFU} / \mathrm{mL}$, 혼합 접종한 경우 $4.09 \times 10^{8} \mathrm{CFU} / \mathrm{mL}$ 으로 더 높았다고 보고 하였다.

\section{효소활성}

유산균을 접종한 콩 발효물의 a-amylase와 protease 활성 을 측정한 결과는 Fig. 3과 같다.

a-amylase 활성 측정 결과, control은 $33.39 \pm 0.21 \mathrm{unit} / \mathrm{mL}$ 으로 가장 높았으며, $\mathrm{I} 13$ 과 JSA22를 접종한 콩 발효물은 $1.05 \pm 0.91,3.13 \pm 1.39 \mathrm{unit} / \mathrm{mL}$ 으로 가장 낮았다. 또한 JSB22 는 $12.56 \pm 1.39 \mathrm{unit} / \mathrm{mL}$ 으로 유산균 접종 콩 발효물 중 가장 
높았다. 콩 발효물의 외관의 경우, control이 유산균을 접종 한 콩 발효물보다 점질물이 많이 형성된 것으로 보아 이는 자연발효로 제조된 청국장과 유사한 외형을 보였다(Fig. 1). Control의 경우, 균주를 접종하지 않은 자연 발효된 청국 장의 형태로 미생물 분포가 유산균뿐만 아니라 Bacillus $\mathrm{sp}$.이 상당히 존재 할 것으로 예측된다. Lee 등(5)은 Bacillus $\mathrm{sp}$.로 제조된 콩 발효물의 경우, $18.45-20.82 \mathrm{unit} / \mathrm{mL}$ 의 a -amylase 활성을 보고한 바 있다.

Protease 활성 측정 결과 control이 $333.13 \pm 17.68 \mathrm{unit} / \mathrm{mL}$ 으로 가장 높았으며, 유산균 접종 콩 발효물은 JSB22 접종 콩 발효물이 $166.67 \pm 2.37$ unit $/ \mathrm{mL}$ 으로 높았다. $\mathrm{Ju}$ 와 $\mathrm{Oh}(17)$ 의 연구에서 유산균과 혼합 배양한 청국장의 protease활성

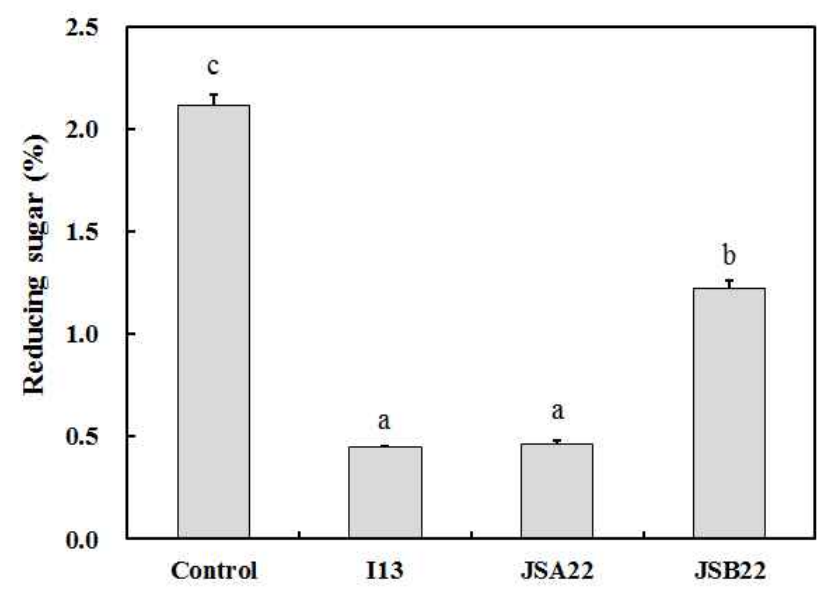

Fig. 4. Reducing sugar contents of fermented soybean products by lactic acid bacteria isolated from fermented soybean paste.

Control, no inoculation; I13, Lactococcus lactis I13; JSA22, Lactobacillus plantarum JSA22; JSB22, $L$. brevis JSB22.

Error bars represent standard deviations $(\mathrm{n}=3)$. Means with different letters $(\mathrm{a}-\mathrm{c})$ above the bars are significantly different $(\mathrm{p}<0.05)$.

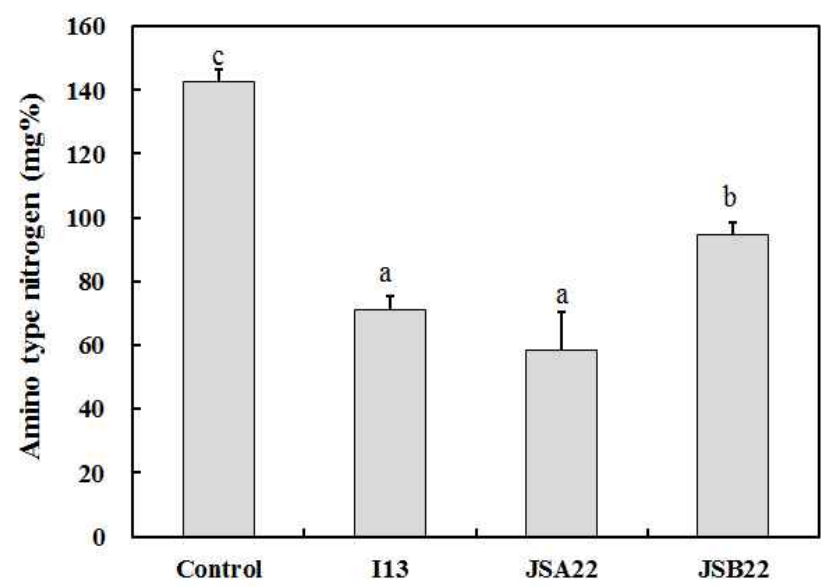

Fig. 5. Amino type nitrogen contents of fermented soybean products by lactic acid bacteria isolated from fermented soybean paste.

Control, no inoculation; I13, Lactococcus lactis I13; JSA22, Lactobacillus plantarum JSA22; JSB22, $L$. brevis JSB22.

Error bars represent standard deviations $(\mathrm{n}=3)$. Means with different letters $(\mathrm{a}-\mathrm{c})$ above the bars are significantly different $(\mathrm{p}<0.05)$.
이 B. subtilis 균주 단독배양 청국장에 비해 낮게 나타난 결과가 혼합 배양 시 B. subtilis 균주의 생육이 다소 억제되 기 때문이라고 보고하였다. 본 연구서도 control이 유산균을 접종한 콩 발효물보다 효소활성이 높게 나타난 것은 유산균 을 접종한 콩 발효물은 유산균이 우점종이 되었으나 control 은 유산균 외의 Bacillus 속 등의 미생물이 자연 접종되어 효소활성이 높게 나타난 것이라고 사료된다.

\section{환원당과 아미노태 질소 함량 측정}

유산균 접종 콩 발효물의 환원당과 아미노태 질소함량을 측정한 결과는 Fig. 4,5 와 같다. 환원당 함량을 측정한 결과, 효소활성과 관련하여 $\operatorname{control}(2.12 \pm 0.05 \%)$ 이 가장 높았고, 유산균 접종 콩 발효물은 JSB22가 $1.23 \pm 0.035 \%$ 로 가장 높 았다. 아미노태 질소 함량 또한 control(142.65 $\pm 3.87 \mathrm{mg} \%)$ 이 가장 높았고 유산균을 접종한 콩 발효물 JSB22가 $94.52 \pm 3.86 \mathrm{mg} \%$ 으로 다른 유산균을 접종한 콩 발효물 보다 높게 나타났다. 이는 amylase와 protease의 활성과 유사한 경향을 보였으며, 이는 발효과정 중 미생물에 의해 생성 또는 분해되는 당과 아미노산 생성량과 연관이 있을 것으로 사료된다.

\section{아미노산과 유기산 함량 측정}

유산균을 접종한 콩 발효물의 아미노산함량을 측정한 결과는 Table 1 과 같다. 측정 결과 총 아미노산 함량은 15.88-17.62\% 범위였다. 유산균 콩 발효물의 경우, glutamic $\operatorname{acid}(2.90-3.30 \%)$ 가 가장 높게 검출되었으며, aspartic $\operatorname{acid}(1.78-2.01 \%)$, arginine(1.30-1.46\%), leusine(1.28-1.44\%) 의 순서로 높게 나타났다. Control의 경우, glutamic acid, aspartic acid, leusine, arginine의 순서로 검출되어 유산균을 접종한 콩 발효물과 유사한 결과를 나타내었다. Song과 Jung(18)의 연구에서 유산균을 이용한 콩 발효물의 아미노 산 함량변화를 측정한 결과, 모든 시료에서 glutamic acid, aspartic acid, leusine, arginine 순으로 많이 함유하고 있으며, glutamic acid와 aspartic acid 2종이 전체 아미노산 함량의 $30 \%$ 정도를 차지하고 있다고 보고하여 본 연구의 결과와 유사하였다. Park등(19)의 연구에서 B. natto를 사용한 청국 장은 phenylalanine, tyrosine, lysine, leucine의 순서로 검출 되었고, B. subtilis $\mathrm{BC}-\mathrm{P} 1$ 유래 청국장은 phenylalanine, glutamic acid, tyrosine, valine순이었다고 보고하였다. 그리 고 Mann 등(20)의 연구에서 B. subtilis MC 31에 의해 발효된 청국장의 경우 아미노산 함량이 leucine, phenylalanine, lysine, valine, tyrosine 순으로 낮아졌다고 보고하여 두 연구 보고는 본 연구와는 상이한 결과를 나타냈다. 이러한 결과 를 통해 발효 균주에 따라 콩 발효 중 생성되는 아미노산이 다름을 알 수 있으며, 유산균을 이용한 발효와 Bacillus 속 균주를 이용한 콩 발효에서 아미노산 함량의 차이가 있음을 확인하였다. 
Table 1. Amino acid content of soybean fermented by lactic acid bacteria isolated from fermented soybean paste

\begin{tabular}{ccccc}
\hline & \multicolumn{4}{c}{ Amino acid (\%) } \\
\cline { 2 - 5 } & Control $^{1)}$ & I13 & JSA22 & JSB22 \\
\hline Aspartic acid & 1.87 & 1.78 & 2.01 & 1.97 \\
Threonine & 0.57 & 0.54 & 0.60 & 0.57 \\
Serine & 0.83 & 0.82 & 0.92 & 0.86 \\
Glutamic acid & 3.18 & 2.90 & 3.30 & 3.22 \\
Proline & 0.90 & 0.85 & 0.95 & 0.91 \\
Glycine & 0.69 & 0.65 & 0.68 & 0.65 \\
Alanine & 0.78 & 0.75 & 0.79 & 0.75 \\
Cystine & 0.09 & 0.07 & 0.08 & 0.07 \\
Valine & 0.89 & 0.85 & 0.89 & 0.90 \\
Methionine & 0.20 & 0.21 & 0.20 & 0.20 \\
Isoleusine & 0.81 & 0.78 & 0.85 & 0.85 \\
Leusine & 1.38 & 1.28 & 1.44 & 1.36 \\
Tyrosine & 0.60 & 0.56 & 0.63 & 0.63 \\
Phenylalanine & 0.94 & 0.84 & 0.97 & 0.93 \\
Histidine & 0.46 & 0.44 & 0.47 & 0.48 \\
Lysine & 1.08 & 1.02 & 1.14 & 1.10 \\
Arginine & 1.31 & 1.30 & 1.46 & 1.42 \\
Tryptophane & 0.27 & 0.25 & 0.26 & 0.25 \\
\hline Total & 16.83 & 15.88 & 17.62 & 17.11 \\
\hline Con & & & \\
\hline
\end{tabular}

${ }^{11)}$ Control, no inoculation; I13, Lactococcus lactis I13; JSA22, Lactobacillus plantarum JSA22; JSB22, $L$ brevis JSB22.

유산균 콩 발효물의 유기산 함량을 분석한 결과는 Table 2 와 같다, control의 경우 succinic $\operatorname{acid}(600.15 \mathrm{mg} / 100 \mathrm{~g})$ 와 oxalic $\operatorname{acid}(63.57 \mathrm{mg} / 100 \mathrm{~g})$ 만 검출되었으며, 유산균을 접종하여 발효한 콩 발효물의 경우 lactic acid가 816.17$3,654.55 \mathrm{mg} / 100 \mathrm{~g}$ 으로 가장 많은 함량을 나타내었고, oxalic acid가 22.74-33.54 mg/100 g 다음으로 많았다. Control을

Table 2. Organic acid content of soybean fermented by lactic acid bacteria isolated from fermented soybean paste

\begin{tabular}{ccccc}
\hline & \multicolumn{4}{c}{ Organic acid (mg/100 g) } \\
\cline { 2 - 5 } & Control $^{1)}$ & I13 & JSA22 & JSB22 \\
\hline Citric acid & $\mathrm{ND}^{2)}$ & $\mathrm{ND}$ & $\mathrm{ND}$ & $\mathrm{ND}$ \\
Succinic acid & 600.15 & $\mathrm{ND}$ & $\mathrm{ND}$ & $\mathrm{ND}$ \\
Lactic acid & $\mathrm{ND}$ & $3,654.55$ & $3,324.19$ & 816.17 \\
Oxalic acid & 63.57 & 33.54 & 32.05 & 22.74 \\
Fumaric acid & $\mathrm{ND}$ & 3.92 & 2.88 & 6.33 \\
Malic acid & $\mathrm{ND}$ & $\mathrm{ND}$ & $\mathrm{ND}$ & $\mathrm{ND}$ \\
\hline
\end{tabular}

${ }^{1)}$ Control, no inoculation; I13, Lactococcus lactis I13; JSA22, Lactobacillus plantarum JSA22; JSB22, L brevis JSB22.

${ }^{2)} \mathrm{ND}$, not detected.
제외하고 모든 군에서 succinic acid는 검출되지 않았으며, control에서는 lactic acid가 검출되지 않았다. Youn 등(21)의 연구 보고에서는 B. subtilis를 접종한 청국장에서는 acetic acid와 lactic acid의 함량이 특이적으로 높았으며 $B$. natto에 서는 citric acid 와 succinic acid가, B. licheniformis에서는 malic acid가 상대적으로 높은 함량을 나타내었다고 보고하 였고, Kim등(22)의 연구에서 B. natto로 발효시킨 청국장에 서 citric acid, acetic acid, pyroglutamic acid의 유기산이 검출 되었다고 보고하여 본 연구 결과와는 상이하였다. 이러한 차이는 발효 균주 차이에 기인하는 것으로 판단되며, 발효 중 생성된 유기산은 유해 균주에 대한 항균효과 및 다양한 풍미에 영향을 주는 것으로 사료된다.

\section{향기분석 측정}

유산균을 접종한 콩 발효물의 향기분석 측정 결과 Table 3.과 같다. 총 39종(ester류 2종, ketose 5종, alcohol 7종, hydrocarbons 14 종, heterocyclic compounds 3 종, acid 4종, other 5종)이 검출되었다. I13을 접종한 콩 발효물에서 23종 의 향기성분이 검출되었고 JSA22를 접종한 콩 발효물 에서 34 종의 향기성분이 JSB22를 접종한 콩 발효물 에서는 19종 의 향기성분이 검출되었다. 세 가지 균주에서 공통적으로 검출된 향기 성분은 formic acid, ethyl ester, acetic acid ethyl ester, 2-butanol, 2,3-butanediol, cyclohexane, methyl-, heptane, benzene, benzene, chloro-, trans-9- fluoro- 2,2,3,3tetramethoxy- 7,7-dimethyl -1-oxaspiro [3,5] non- 5- ene, hexadecane, naphthalene, pyrrolidine, 1-(1- isobutyl3-methyl-1- butenyl)-, disulfide, dioctyl, diethyldisulfide 총 14종 이였으며 그 중에서도 benzene(81.43-98.54 ppm) 과 acetic acid, ethyl ester(44.79-56.74 ppm)가 많이 검출되었다. I13과 JSA22 접종 구에서 공통적으로 7종의 향기성분이 검출되었으며 그 중에서도 propane(I13: $95.23 \mathrm{ppm}$, JSA22: $97.33 \mathrm{ppm}$ )이 가장 많이 검출되었다. 여러 보고에 따르면 Bacillus 속으로 제조된 청국장과 natto의 특이한 향기성분 으로 알려진 pyrazine류 화합물인 di-, tri-, tetramethylpyrazine 화합물이 주로 검출된다고 보고되었다(21.23). 본 연구의 유산균을 이용한 콩 발효물에서는 pyrazine류의 화합물이 검출되지 않았으며, 유산균주 별 콩 발효물의 향기성분이 분석 된 바 없기 때문에 균주에 따른 향기특성 기초자료로 유용할 것으로 사료된다.

\section{요 약}

전통장류로부터 분리 된 효소 활성 및 probiotic효과가 우수한 유산균을 접종하여 제조된 콩 발효물의 품질특성을 분석하였다. 일반세균수는 유산균을 접종한 콩 발효물이 $4.10 \times 10^{9}-7.75 \times 10^{9} \mathrm{CFU} / \mathrm{mL}$ 으로 나타났다. 유산균수를 측 
Table 3. Volatile flavor compounds content of soybean fermented by lactic acid bacteria isolated from fermented soybean paste

\begin{tabular}{|c|c|c|c|c|}
\hline Flavor compounds & $\mathrm{RT}^{1)}(\min )$ & $\mathrm{I} 13^{2)}$ & JSA22 & $\begin{array}{l}\text { (unit: ppm) } \\
\text { JSB22 }\end{array}$ \\
\hline \multicolumn{5}{|l|}{$<$ Esters $>$} \\
\hline formic acid, ethyl ester & 7.076 & 2.87 & 2.02 & 1.74 \\
\hline acetic acid ethyl ester & 8.495 & 51.37 & 56.74 & 44.79 \\
\hline \multicolumn{5}{|l|}{$<$ Ketones $>$} \\
\hline 2-butanone & 8.901 & 5.60 & 3.63 & $\mathrm{ND}^{3)}$ \\
\hline 2-butanone, 3-methyl- & 11.744 & 0.68 & 0.81 & $\mathrm{ND}$ \\
\hline cyclohexanone & 59.011 & ND & 4.57 & $\mathrm{ND}$ \\
\hline 1-pentanone, 4,5-dimethoxy-2,2-dimethyl-1-phenyl- & 67.049 & ND & 3.76 & $\mathrm{ND}$ \\
\hline 3-thiolannone & 84.883 & ND & 8.74 & $\mathrm{ND}$ \\
\hline \multicolumn{5}{|l|}{$<$ Alcohols $>$} \\
\hline 2-hydroxypropane & 9.974 & ND & $\mathrm{ND}$ & 1.60 \\
\hline 2-butanol & 14.085 & 3.69 & 3.90 & 10.56 \\
\hline 2-propanol & 30.840 & 40.85 & 19.36 & $\mathrm{ND}$ \\
\hline $\begin{array}{l}\text { bicyclo[4.1.0]hept-3-ene-2-thiol, 3,7,7-trimethyl-, } \\
\text { [1s-(1.alpha.2.alpha.,6.alpha.)]- }\end{array}$ & 42.784 & $\mathrm{ND}$ & $\mathrm{ND}$ & 1.87 \\
\hline 2,3-butanediol & 44.449 & 0.68 & 0.94 & 2.81 \\
\hline 2-naphthalenol, 1,2-dihydro-1,1-dimethyl-, acetate & 72.001 & 0.14 & 0.40 & $\mathrm{ND}$ \\
\hline 1,1-dimethoxy-3,3-dimethyl-2-butanol & 81.283 & ND & 0.54 & $\mathrm{ND}$ \\
\hline \multicolumn{5}{|l|}{$<$ Hydrocarbons $>$} \\
\hline cyclohexane, methyl- & 6.104 & 16.12 & 16.81 & 16.31 \\
\hline heptane & 6.342 & 2.32 & 2.42 & 2.27 \\
\hline 1,4-dioxane, 2,5-dimethyl- & 9.838 & 0.82 & 0.81 & ND \\
\hline benzene & 10.159 & 81.43 & 82.56 & 98.54 \\
\hline benzene, chloro- & 25.448 & 3.42 & 3.50 & 3.48 \\
\hline propane & 41.968 & 95.23 & 79.33 & $\mathrm{ND}$ \\
\hline 1-acetoxy-2,5-ochtodadiene & 43.703 & ND & 2.02 & $\mathrm{ND}$ \\
\hline trans-9-fluoro-2,2,3,3-tetramethoxy-7,7-dimethyl-1-oxaspiro[3,5]non-5-ene & 44.058 & 0.68 & 0.94 & 0.53 \\
\hline hexadecane & 50.188 & 0.82 & 1.08 & 0.94 \\
\hline naphthalene & 56.034 & 0.82 & 1.21 & 4.14 \\
\hline methylnaphthalene & 61.605 & ND & $\mathrm{ND}$ & 8.16 \\
\hline 1-phenyl-4-penten-1-yne & 66.917 & $\mathrm{ND}$ & $\mathrm{ND}$ & 2.27 \\
\hline (triethylsilyl)germane & 73.258 & 0.14 & 0.40 & $\mathrm{ND}$ \\
\hline cis-2,3-epoxyheptane & 85.817 & ND & 3.76 & $\mathrm{ND}$ \\
\hline \multicolumn{5}{|l|}{$<$ Heterocyclic compounds $>$} \\
\hline 2-acetyltetrahydrofuran & 7.949 & 1.78 & 0.67 & $\mathrm{ND}$ \\
\hline pyrrolidine, 1-(1-isobutyl-3-methyl-1-butenyl)- & 22.900 & 23.64 & 23.93 & 22.86 \\
\hline \multicolumn{5}{|l|}{$<$ Acids $>$} \\
\hline acetic acid & 41.520 & ND & $\mathrm{ND}$ & 90.65 \\
\hline 1-cyclopentene-1-carboxylic acid & 77.092 & ND & 19.36 & $\mathrm{ND}$ \\
\hline 2-propenoic acid, 2-methyl & 82.173 & ND & 2.02 & $\mathrm{ND}$ \\
\hline hexadecanoic acid, ethyl este & 83.683 & ND & 4.57 & $\mathrm{ND}$ \\
\hline \multicolumn{5}{|l|}{$<$ Others $>$} \\
\hline disulfide, dioctyl & 24.182 & 1.91 & 0.40 & 0.80 \\
\hline diethyldisulfide & 25.311 & 0.82 & 0.94 & 1.07 \\
\hline formamide, n-formyl-n-methyl- & 65.152 & 7.51 & 8.74 & $\mathrm{ND}$ \\
\hline 1-(1,3-benzodioxol-5-yl)-n-ethyl-2-propanamine & 74.866 & ND & 3.50 & $\mathrm{ND}$ \\
\hline acetamide, 2-(diethylamino)-n-(2,6-dimethylphenyl)- & 81.975 & $\mathrm{ND}$ & 79.33 & $\mathrm{ND}$ \\
\hline
\end{tabular}

\footnotetext{
${ }^{1)} \mathrm{RT}$, retention time.

${ }^{2}$ I13, Lactococcus lactis I13; JSA22, Lactobacillus plantarum JSA22; JB22, L brevis JSB22.

${ }^{3)} \mathrm{ND}$, not detected.
} 
정 결과 유산균을 접종한 콩 발효물은 $2.85 \times 10^{9}-4.35 \times 10^{9}$ $\mathrm{CFU} / \mathrm{mL}$ 으로 높게 나타났다. a-Amylase 활성 측정 결과 I13과 JSA22를 접종한 콩 발효물은 $1.05 \pm 0.91,3.13 \pm 1.39$ unit $/ \mathrm{mL}$ 으로 가장 낮았다. 또한 JSB22는 $12.56 \pm 1.39$ unit $/ \mathrm{mL}$ 으로 유산균 접종 콩 발효물 중 가장 높았다. Protease 활성 측정 결과, control이 $333.13 \pm 17.68$ unit $/ \mathrm{mL}$ 으 로 가장 높았으며, 유산균을 접종한 콩 발효물은 JSB22를 접종한 콩 발효물이 $166.67 \pm 2.37$ unit/mL으로 높았다. 환원 당 함량을 측정한 결과 유산균 접종 콩 발효물 중 JSB22가 $1.23 \pm 0.035 \%$ 로 가장 높았다. 아미노태 질소 함량 또한 JSB22가 $94.52 \pm 3.86 \mathrm{mg} \%$ 으로 높게 나타났다. 아미노산함 량을 측정한 결과 glutamic acid, aspartic acid, arginine, leusine 순으로 많이 함유하고 있었다. 유기산 함량을 분석 한 결과 lactic acid, oxalic acid가 많이 측정되었다. 향기분석 측정 결과 총 39 종(ester류 2종, ketose 5종, alcohol 7종, hydrocarbons 14 종, heterocyclic compounds 3 종, acid 4종, other 5종)이 검출되었다. 세 가지 균주에서 공통적으로 benzene(81.43-98.54 ppm)과 acetic acid, ethyl ester(44.79$56.74 \mathrm{ppm}$ )가 많이 검출되었다. 본 연구는 전통장류 유래 기능성 우수 유산균주를 이용한 콩발효물의 기초적 품질특 성에 관한 내용으로 미생물학적 및 이화학적 관련 특성을 분석하여 제시하였다. 유산균 이용 생물전환에 의한 다양 한 기능성 물질이 생성 되었을 것으로 생각된다. 본 연구 결과가 기능성 콩 발효소재 개발의 좋은 기초자료가 될 것으로 생각되며, 장류 품질개선 기능성 스타터 개발에 활 용 될 수 있을 것으로 기대된다.

\section{감사의글}

본 연구는 농촌진흥청 국립식량과학원 연구개발 과제 (PJ01269801)의 지원에 의한 연구결과의 일부로 이에 감사 드립니다.

\section{References}

1. Cui CB, Oh HS, Park JC, Nam KB, Lee DS, Ham SS (2004) Antioxidative, antimutagenic and cytotoxic effects of functional food manufactured from fermented soybean extract. Korean J Food Preserv, 11, 214-220

2. Chung WY, Kim SK, Son JY (2008) Isoflavones contents and physiological activities of soybeans fermented with Aspergillus oryzae or Bacillus natto. J Korean Soc Food Sci Nutr, 37, 141-147

3. Beak LM, Kang KM, Park LY, Lee SH (2012) Fermentation and quality characteristics of Cheongkookjang prepared with germinated soybean. Korean J Food Preserv, 19, 547-553

4. Baek LM, Park LY, Park KS, Lee SH (2008) Effect of starter cultrues on the fermentative characteristics of Cheonggukjang. Korean J Food Sci Technol, 40, 400-405

5. Lee SY, Eom JS, Choi HS (2014) Quality characteristics of fermented soybean products by Bacillus sp. isolated from traditional soybean paste. J Korean Soc Food Sci Nutr, 43, 756-762

6. Yang M, Kwak JS, Jang SR, Jia Y, Park IS (2013) Fermentation characteristics of soybean yogurt by mixed culture of Bacillus sp. and lactic acid bacteria. Korean J Food Nutr, 26, 273-279

7. Jang JK, Yoo SH (1997) Preparation of soy yogurt using isolated soybean protein and whey powder. J Korean Soc Food Sci Nutr, 26, 1128-1134

8. Lee JE, Lee SY (2001) Growth characteristics of Bifidobacteria and quality characteristics of soy yogurt propared with different proteolytic enzymes and starter culture. Korean J Food Sci Technol, 33, 603-610

9. Jung HK, Kim EY, Yae HS, Choi SJ, Jung JY, Juhn SL (2000) Cholesterol-lowering effect of lactic acid bacteria and fermented milks as probiotic functional foods. Food Industry and Nutrition, 5, 29-35

10. Ann YG (2011) Probiotic lactic acid bacteria, Korean J Food Nutr, 24, 817-832

11. Tannock GW (1997) Probiotic properties of lactic acid bacteria: plenty of scope for fundamental R\&D. Trends Biotechnol, 15, 270-274

12. Ahn YJ, Choi HS (2014) Potential probiotic properties of exopolysaccharide producing lactic acid bacteria isolated from fermented soybean product, J. Korean Soc Food Sci Nutr, 43, 749-755

13. Kim HJ, Lee JJ, Cheigh MJ, Choi SY (1998) Amylase, protease, peroxidase and ascorbic acid oxidase activity of kimchi ingredients. Korean J Food Sci Technol, 30, 1333-1338

14. Choi HS, Joo SJ, Yoon HS, Kim KS, Song IG, Min KB (2007) Quality characteristics of Hwangki (Astragalus membranaceus) Cheongkukjang during fermentation. Korean J Food Preserv, 14, 356-363

15. Miller GL, Blum R, Glennon WE, Burton AL (1960) Measurement of carboxymethylcellulase activity. Anal Biochem, 1, 127-132

16. Lee SY, Park NY, Kim JY, Choi HS (2012) Quality characteristics of rice-doenjang during fermentation by differently shaped Meju and adding starter. Korean J Food 
Nutr, 25, 505-512

17. Ju KE, Oh NS (2009) Effect of the mixed culture of Bacillus subtilis and Lactobacillus plantarum on the quality of Cheonggukjang. Korean J Food Sci Technol, 41, 399-404

18. Song HN, Jung KS (2006) Quality characteristics and physiological activities of fermented soybean by lactic acid bacteria. Korean J Food Sci Technol, 38, 475-482

19. Park SY, Bang MA, Oh BJ, Park JH, Song WS, Choi KM, Choung ES, Boo HO, Cho SS (2013) Fermentation and quality characteristics of Cheonggukjang fermented with Bacillus subtilis BC-P1. Korean J Microbiol, 49, 262-269

20. Mann SY, Kim EA, Lee GY, Kim RU, Hwang DY, Son HJ, Lee BW, Lee CY, Kim DS (2013) Characteristics of Chungkookjang produced by Bacillus subtilis MC31. J Life Sci, 23, 560-568

21. Youn KC, Kim DH, Kim JO, Park BJ, Yook HS, Cho JM, Byun MW (2002) Quality characteristics of the Chungkookjang fermented by the mixed culture of Bacillus natto and B. licheniformis, J Korean Soc Food Sci Nutr, 31, 204-210

22. Kim BR, Park CH, Ham SS, Lee SY (1995) Flavor component, fatty acid and organic acid of Natto with spice added. J Korean Soc Food Nutr, 24, 219-227

23. Kim DH, Lim DW, Bai S, Chun SB (1997) Fermentation characteristics of whole soybean Meju model system inoculated with 4 Bacillus strains. Korean J Food Sci Technol, 29, 1006-1015 